\title{
Metallurgical knowledge transfer from Asia to Europe
}

Retrospect of Chinese paktong and its influence on Sweden and Austria Transfert de savoir métallurgique de l'Asie en Europe : coup d'oil rétrospectif sur le paktong chinois et son influence en Suède et en Autriche

\section{Chao Huang}

\section{(2) OpenEdition \\ 1 Journals}

Electronic version

URL: http://journals.openedition.org/artefact/1996

DOI: $10.4000 /$ artefact.1996

ISSN: 2606-9245

Publisher:

Association Artefact. Techniques histoire et sciences humaines, Presses universitaires du Midi

\section{Printed version}

Date of publication: 6 December 2018

Number of pages: 89-110

ISBN: 978-2-8107-0595-5

ISSN: 2273-0753

Electronic reference

Chao Huang, « Metallurgical knowledge transfer from Asia to Europe », Artefact [Online], 8| 2018,

Online since 21 June 2019, connection on 27 November 2020. URL : http://journals.openedition.org/ artefact/1996; DOI : https://doi.org/10.4000/artefact.1996

\section{cc) (†) $\odot$}

Artefact, Techniques, histoire et sciences humaines est mise à disposition selon les termes de la Licence Creative Commons Attribution - Pas d'Utilisation Commerciale - Pas de Modification 4.0 International. 


\section{Metallurgical knowledge transfer from Asia to Europe}

Retrospect of Chinese paktong and its influence on Sweden and Austria

\section{Chao Huang}

\section{Abstract}

The invention of paktong (白銅), literally “white copper”, was known in ancient China from at least the 4th century $A D$ and is considered one of the most important inventions in the history of metallurgy, facilitating economic and material exchange in Europe during the $17-19^{\text {th }}$ centuries. As recent investigations into the history of paktong show, it is generally recognised that the manufacturing of this metal had close associations with Southwest China. The acquisition of this metallurgical knowledge in Europe had very close relationship with Sweden and Austria. In this paper, the author will combine textual materials and field research findings to shed new light on the influence of paktong on $18-19^{\text {th }}$ century Europe.

\section{Keywords}

paktong, German-silver, nickel, Sweden, Austria

99 Chao Huang, « Metallurgical knowledge transfer from Asia to Europe », Artefact, 8 , 2018, p. 89-110. 


\section{Transfert de savoir métallurgique de l'Asie en Europe : coup d'oeil rétrospectif sur le paktong chinois et son influence en Suède et en Autriche}

\section{Résumé}

L'invention du paktong (白銅), littéralement « cuivre blanc », était connue dans la Chine ancienne depuis au moins le Ive siècle apr.J.-C. et est considérée comme l'une des inventions les plus importantes dans l'histoire de la métallurgie, facilitant les échanges économiques et matériels en Europe du xvII ${ }^{e}$ au xIx siècle. De récentes recherches sur l'histoire du paktong ont montré que la fabrication de ce métal avait des liens étroits avec le Sud-Ouest de la Chine. L'acquisition de connaissances sur ce métal en Europe est liée à la Suède et à l'Autriche. Dans cet article, l'auteur combinera les matériaux textuels et les résultats d'enquêtes de terrain pour jeter une nouvelle lumière sur l'influence du paktong sur l'Europe du xVIII ${ }^{e}$ au xIx siècle.

\section{Mots-clés}

paktong, allemand-argent, nickel, Suède, Autriche

\section{Acknowledgements}

This research is supported by 2017 Humanities and Social Science Research on Youth Fund Project of the Education Ministry (Project No. 17YJC770011), the China Postdoctoral Science Foundation (Project No. 2016M602576), and the Guangdong Philosophy and Social Science Fund for the 13th Five-Year Plan Funded Project for Youth (Project No. GD16YLS02). Grateful thanks are due to Professors Rubin Han and Jianjun Mei for their kind support and help. I also would like to thank Professors Paul A. Van Dyke and Yinghe Jiang for their considerable encouragement and assistance during the preparation of this paper. Appreciation to work of editing this paper is due to Mr Adrien von Ferscht; $\mathrm{Mr}$ Christoph Fahrenson for SEM-EDS results and Ms Irene Preuß for photo-taking of the images at ZELMI (TU-Berlin). Any remaining errors are my responsibility. 


\section{Introduction}

Paktong is an alloy that can trace its roots in China to the $4^{\text {th }}$ century AD. It is a blend of copper-nickel or copper-nickel-zinc alloy. The name is derived from the Chinese "baitong", meaning "white copper." In MingQing China, it was widely used for making every day domestic items such as water pipes for smoking, bowls, dishes, ink boxes, and so on. In the late 17 th century, it was frequently exported to Europe where it became fashionable for decorative domestic wares such as candlesticks, candle snuffers and ornamental fire grates. It was embraced and became popular across European countries because of its metallic nature and mainly because of its ease of care and upkeep. Before the discovery of nickel by Swedish mineralogists, the exact chemical compositions of paktong were still a mystery to anybody that was keen to reproduce it, using local minerals in Europe. European scientists and industrialists were later trying very hard to understand the chemical composition of paktong, and as a result of these endeavours, they produced similar copper-nickel-zinc alloys under various names such as German-silver or nickel silver.

The metallurgical knowledge behind paktong was then quite complicated, and it was not easy for the West to understand the alloy and imitate it in its correct form. The complexities of the manufacturing process were discussed and investigated in ground-breaking research by Jianjun Mei and his colleagues in the late of $20^{\text {th }}$ century. ${ }^{1}$ It provides concrete evidence to uncover that how paktong was produced in ancient China. Mei's discourses on the smelting and refining of paktong were based on a combination of accounts found in ancient textual material and also through field research of some smelting sites in Sichuan. ${ }^{2}$ According to textual and firsthand accounts, some of the misconceptions and misinformation which arose over an extended period of history were able to be dispelled.

Among extant records, early descriptions of the metallurgical process for manufacturing paktong are mentioned. In the Gazetteer of Huili County of 1870 , for example, it tells that paktong was smelted from a mixture of

1. Shuyun Sun et al., "Paktong - Ancient metallurgy of cupronickel and nickel silver in China", in Gong Jin Ji, Beijing, Science Press, 2015; Jianjun MeI and Tsun Ko, "Studies on ancient metallurgy of cupronickel in China”, Studies in the History of Natural Sciences 8, n 1, 1989, p. 67-77.

2. Ibid. 
"blue ore" and "yellow ore" and that mining the ores required for a tax to be paid to the Qing Court. As Mei's experimental and research results show, paktong was smelted by mixing pentlandite, $(\mathrm{FeNi})_{9} \mathrm{~S}_{8}$ embedded in olivine, and copper ores together, through an extremely complicated process that resulted in a copper-nickel alloy or cupro-nickel. This process required smelting that was repeated 6 or 7 times, resulting in little impurity. It was then finally alloyed with zinc which was then made it suitable for producing small articles and domestic items. ${ }^{3}$

This process and metallurgical mastery of paktong had been concealed from the West for centuries. Only after the discovery of nickel by Cronstedt in $1751^{4}$ and the chemically analytical results of paktong from Engeström in $1776^{5}$, its nature gradually became apparent to European scientists. In the early $19^{\text {th }}$ century, for example, Hofrath Ch. Keferstein presented an investigative report at the meeting of the German Explorers of Nature at Halle, stating that paktong was smelted in China from a kind of ore and consisted principally of copper and nickel. ${ }^{6} \mathrm{He}$ considered that there were two chemicals and mining ways to produce paktong, and the former method would be highly likely to succeed in being able to produce the nickel-copper alloy on a large scale. He also determined it was desirable that more actual experiments should be conducted with this goal in mind by philosophical chemists as well as by practical metallurgist. ${ }^{7}$ His deduction was correct, but it had taken a long time for his contemporary European scientists to realise that the crucial technology of paktong's metallurgical significance lay in the mining and smelting of the copper with nickel minerals, pentlandite, and not on chemically melting separate pure metals to produce the alloy.

3. Jianjun MeI, "The history, metallurgy and spread of paktong," Bulletin of the Metals Museum 24, 1995, p. 45-47.

4. Axel F.Cronstedt, "Rön och försök gjorde med en malm-art, från Los kobolt grufvor i Färila Socken och Helsingeland”, Kungliga Svenska Akademiens Handlingar 12, 1751, p. 287-292.

5. Gustavus von Engeström, "Pak-Fong, En Chinesisk Huit Metall," Kungliga Svenska Akademiens Handlingar, 37, 1776, p. 36-38.

6. Hofrath Keferstein, "Ueber Weisskupfer: Eine Volesung, Gehalten Am 18. Septbr. in Der Versammlung Der Deutschen Naturforscher Und Aerzte Zu Halle", Journal Fur Chemie Und Physik, 26, 1823, p. 17-57.

7. Ibid. 


\section{The retrospective and scholarly fascination around paktong and its research}

Despite the fact that Chinese paktong has long been a part of the world history, and the scholarly pursuit of its history can only be traced back to the 1920s. Berthold Laufer, a German-American scholar, was one of the earliest people to refer to paktong in 1919. In his book, he mentioned: "It is well known that the Chinese have a peculiar alloy of copper, consisting of copper 40.4, zinc 25.4, nickel 31.6, iron 2.6, and occasionally some silver and arsenic. It looks white or silver-like in the finish and is hence called pai-t'un (white copper). In Anglo-Indian, it is tootnague (Tamil tutunāgum and Portuguese tutanaga). It is also known to foreigners in the

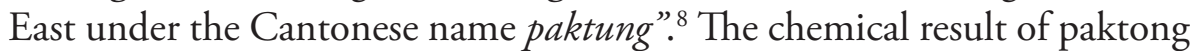
here is from Fyfe's early research about such metal in $1823^{\circ}$, but the nickel content here is comparatively higher than the ordinary paktong of late Imperial China.

Alfred Bonnin was the earliest Englishman to carry out comprehensive research into the history of paktong. He published in 1924 the first treatise on paktong. ${ }^{10}$ This publication was the result of a significant amount of research into what was then an insufficient field of interest, delving into a variety of English textual material of that period. Bonnin investigated and discussed several aspects of paktong such as the naming, provenance, utilisation, and so on. Most of the material he incorporated in the book was taken from dictionaries, novels, records, travelogues and journals of the $18-20^{\text {th }}$ centuries, all of which were published in either English or other European languages with English translations. The manner in which Europe initially and actively knew paktong could be directly linked to the research conducted by the people into this Chinese alloy. From later research into this phenomenon, it can be deduced that the paktong in the $18^{\text {th }}$ century Europe occurred as a result of private importation from

8. Berthold Laufer, Sino-Iranica: Chinese Contributions to the History of Civilization in Ancient Iran, Field Museum of Natural History, Chicago, 1919, p. 555.

9. Andrew Fyfe, "Analysis of Tutenag, or the White Copper of China", The Edinburgh Philosophical Journal, 7, 1823, p. 69-71.

10. Alfred Bonnin, Tutenag \& Paktong, with Notes on Other Alloys in Domestic Use during the Eighteenth Century, Oxford, Oxford Press, 1924. 
China. Bonnin's treatise is the first historical research into paktong and was of great importance to followers of Bonnin on this specific topic in both China and Europe. Zigong Zhang was the first Chinese scholar to read and use the book. His mid-20 $0^{\text {th }}$-century research into paktong that had a particular focus on the history of chemistry for the early use of nickel alloy in ancient China. ${ }^{11}$

In 1925, Hongzhao Zhang quoted Laufer's words about paktong in one of his papers that discussed the origin of zinc in China. He threw light on the fact that the Chinese character " $w u$ " (添) first appeared in "Shi Jing" (Classic of Poetry, Classic of Odes, Poetry or Songs) dating from the $11^{\text {th }}$ to $7^{\text {th }}$ centuries BC. However, Zhang's reason for mentioning this character in his research was not especially paktong-centric but was intended to emphasise the fact on purpose that zinc had earlier been used in ancient China. ${ }^{12}$ In the same year, the parts on minerals and metals from Laufer's book were translated into Chinese by Zhang, noting that nickel and zinc were important ingredients for making paktong, both of which were not accidental elements of the metal but were artificial additions. He also mentioned that an alloy called "German-silver" had been produced in Germany as a result of an experimental and analytical investigation into paktong. ${ }^{13}$

Jin Wang published in 1929 a Chinese article entitled On the Chinese Copper Alloys Containing Nickel and indicated: "According to western textual records, the use of cupro-nickel alloy in China has a long history, so the name for the alloy of nickel and copper was called China Silver, and also Packfong. It was a misspelling from the pronunciation of paktong." ${ }^{14}$ Wang reminded us that the Chinese had been using paktong for a long time, and it was the earliest cupro-nickel alloy in the world. As early as the Tang Dynasty, paktong was regarded as a precious metal, but there were many types of silvery white copper similar to paktong such as copper alloyed with more lead and tin that resulted a form of white copper. In

11. Zigong Zhang, "On Chinese nickel paktong and its role in the historical relations between Europe and Asia”, Kexue (Science), 33, n 2, 1957, p. 91-99.

12. Hongzhao Zhang, "Re-Discussion on the Origin of Utilization on Zinc in China", Kexue (Science), n ${ }^{\circ}$ 9, 1957, p. 1116-1127.

13. Hongzhao Zhang, Translation and Research on Berthold Laufer's Sino-Iranica of the Mineral and Metal Section, Institute of Geology under the Ministry of Agriculture and Commerce, Nanjing, 1925.

14. Jin WANG, "On the Chinese copper alloys containing nickel”, Kexue (Science), 13, n 10, 1929, p. 1418-1419. 
medieval China, white copper was not always paktong according to historical contexts. The silvery whiteness of paktong is the result of its nickel content. It was then not possible to extract and purify nickel from ores, but the nickel alloy did exist. The manufacturing and metallurgical processes of paktong are derived from the addition of nickel minerals, with the most commonly used nickel minerals being Kupfer Nickel, Nickel Glance and Nickel Bland (blende). Thus, the first contains NiAs as a chief constituent, the second contains $\mathrm{NiAs}_{2}$ as a chief constituent, and the third contains $\mathrm{NiS}$ as a chief constituent with trace arsenic. Unfortunately, it was not easy for the ancient Chinese to identify the arsenic minerals from nickel minerals. The traditional medical doctor Shizhen $\mathrm{Li}$ recorded that a kind of white copper was from Yunnan and was produced by mixing arsenic minerals with copper, as in the recorded descriptions in Tian Gong Kai Wu (The Exploitation of the Works of Nature) of the use of arsenic minerals to make white copper. So the arsenic minerals were mainly mentioned as those minerals containing nickel. Wang's article, therefore, is the first research relying on literature about paktong in modern China. His work gives us three crucial academic pointers. Firstly, the many white coppers referred to in ancient literature or records were not all paktong or cupro-nickel alloy, but were other existing types of copper alloys. Secondly, paktong was smelted from nickel and arsenic minerals. Finally, the records of smelting white copper in Ben Cao Gang Mu (Compendium of Materia Medica) and Tian Gong Kai Wu using arsenic minerals probably contain nickel content, which are nickel and arsenic minerals.

In 1936, the Chinese scholar Shen Lin made mention of German paktong, which is German-silver, in his research paper entitled The Manufacture of German Paktong. He maintained that the emergence of German-silver originated as a direct result of the research into paktong. Numerous scientific explanations in his paper were translated, more referring to Westerners' achievements. Lin also mentioned that different compositions of Germansilver have a precise parallel relationship with hardness, irrigation castability and isotherms of liquid chromatography. ${ }^{15}$

In 1957, Zigong Zhang, in his paper On Chinese Nickel Paktong and its Role in the Historical Relations between Europe and Asia, cited Hongzhao

15. Shen LiN, "The metallurgical manufacture of German paktong", Crafts Quarterly (Gongyi Jikan), 1, 1936, p. 40-45. 
Zhang's ancient textual records of paktong and pointed out there were at least three places in ancient Yunnan where the manufacturing of paktong occurred. ${ }^{16}$ They were located in Tanglang County, Leima Mountain in Yuanmou County and Matai in Dingyuan County. In the same year, C. F. Cheng and C. M. Schwitter published a paper entitled Nickel in Ancient Bronzes. ${ }^{17}$ They discussed the nickel content in ancient metallic artefacts using indications derived from ancient Asian bronzes containing nickel and its percentage in the alloy. They also believed that Bactrian nickel alloy bore a similarity to paktong; however, their viewpoint and arguments were vehemently rejected by Schuyler Cammann, resulting in condemnation and unnecessarily sharp words. ${ }^{18}$ Both parties wrote two papers on the early nickel content of ancient artefacts, though there was no precise and conclusion for ensuing debate, with Cammann arguing it was even too weak to be convincing at all. ${ }^{19}$

In 1970, W. D. John and K. Coombes published the other book about paktong and some of its history related to a Scott. They emphasised the importance of the Scottish neo-classical architect Robert Adam's early adoption of paktong as a favoured material. ${ }^{20}$ Adam was one of the earliest neo-classical designers to use the metal to make decorative objects for the many now famed neo-classical buildings he designed in England and Scotland. The end of this book contains several illustrations of paktong fire grates, fireplace accessories and candlesticks, together with brief descriptions.

In 1974, Joseph Needham summarised former scholars' research about paktong in one of his volumes of Science and Civilisation in China. He conducted a comprehensive research and analysis of the history of paktong, accepting Wang's views on paktong. It was considered that it was smelted

16. H. ZHANG, "On Chinese nickel paktong and its role in the historical relations between Europe and Asia," op. cit., p. 92-93.

17. C.F. Cheng and C.M Schwitter, "Nickel in ancient bronzes", American Journal of Archaeology, 61, n 4,1957, p. 351-365.

18. Schuyler V. R. Cammann, “The 'Bactrian Nickel Theory,” American Journal of Archaeology, 62, $n^{\circ} 4,1958$, p. 409-414.

19. Schuyler V. R. Cammann, "On the renewed attempt to revive the 'Bactrian Nickel Theory", American Journal of Archaeology, 66, ${ }^{\circ}$ 1, 1962, p. 92-94.

20. W.D. John and K. Coоmbes, Paktong: The Non-Tarnishable Chinese "Silver" Alloy Used for "Adam" Firegrates and Early Georgian Candlesticks, Newport, Monmouthshire, The Ceramic Book Company, 1970. 
by mostly kupfernickel (NiAs) and nickel glance (NiAsS) by Chinese historical records. Conversely, he keenly noticed that the nickel minerals in Sichuan and Yunnan in China contained $\mathrm{CuFeS}_{2}$ and $\mathrm{NiFeS}$, inferring that paktong was the product of a mixture of nickel-copper sulphides. These sulphides must have been smelted at very low temperatures preventing their fusion, while permitting the complete removal of the sulphur and the production of mixed oxides which could readily be reduced to become mixed metals. According to Ferdinand von Richthofen's geological records, Needham also maintained that Huili of Sichuan must have been a centre of nickel production in the late Qing Dynasty. ${ }^{21}$ It can be said that Needham epitomised the textual investigation of paktong and his discovery of the characteristics of nickel minerals in Yunnan and Sichuan led to an entirely new era of paktong research. However, despite Needham realising that ancient records about nickel minerals relating to nickel-arsenic ores were different from the widely existing records of iron-nickel ore in Yunnan and Sichuan, no further progress was made on research.

In 1989, Jianjun Mei and Tsun Ko published a paper about the in-depth research on paktong in China, which initially used comprehensive research from field research and experimental analysis, according to recent geographical reports. ${ }^{22}$ It proved that in Limahe, Xiaoguanhe, Lixi and Qingkuangshan ancient metallurgical sites of paktong existed in Sichuan. When it was investigated and debated the smelting process of paktong, it became clear that the recorded manufacturing process had four steps to produce the alloy. They also considered that the famous "Yunnan Paktong" was produced from the smelted cupro-nickel alloy with appropriate additions of copper and zinc or brass for the melting of the copper-nickel-zinc ternary alloy. The blending components and colours were always carried out in Yunnan province, such as in Kunming, Huize, and so on then transported to other Chinese provinces or exported abroad. The primary contributions of this paper revealed the existence and meaning of ancient metallurgical sites and the manufacturing process of paktong through field research and experimental analysis. It also provided a proof that Huili in

21. Joseph Needham, Science and Civilisation in China, Vol. 5, Part II, Cambridge, Cambridge University Press, 1974, p. 227.

22. J. Mer and T. Ko, "Studies on Ancient Metallurgy of Cupronickel in China," op. cit., p. 67-77. 
Sichuan was once a centre for manufacturing paktong, echoing Needham's previous significant discovery. ${ }^{23}$

1995 saw Brian Gilmour and Eldon Worrall publishing their scientific research paper on paktong, using plenty of the well-preserved metallic artefacts from the UK museums and private collections. ${ }^{24}$ They briefly discussed some issues of the production of paktong and its introduction to the West using analytical results of extant paktong collections. Gilmour and Worrall also demonstrated the compositional characteristics of paktong in the data from their experiments as follows: "paktong is an early form of nickel brass and may be defined as a ternary alloy containing approximately 5-20\% nickel, 40-65\% copper and 20-50\% zinc". ${ }^{25}$ In the same year, Mei continued publishing his research findings on paktong in his article entitled The History, Metallurgy and Spread of Paktong. ${ }^{26}$ In this English version of his work, he combined his previous research with his more recent work and also confirmed as a fact that "Yunnan Paktong" had been introduced into the West. It was a significant statement since it had been widely believed that the decline of the paktong industry in China during the Qing Dynasty was mainly due to Western attempts to copy paktong and the consequent emergence of German-silver led to the declined production of the alloy in Qing China. ${ }^{27}$

In 1999, Keith Pinn also published a treatise about paktong in Europe that focused on the regional research of the metal in $18^{\text {th }}$ century Britain, particularly in Birmingham where was one of the most important manufacturing centres for metallic items and objects d'art at that time. Pinn retraced and investigated the history of the introduction of paktong that led him to discover Matthew Boulton's extensive archives. It is here that he learnt about the arrival of paktong in Britain and he researched notes on the discussions about the so-called reproduction of paktong among scientists of the Lunar

23. J. Needham, Science and Civilisation in China, Vol. 5, Part II, op. cit., p. 227.

24. Brian Gilmour and Eldon Edward Worrall, "Paktong: the trade in Chinese nickel brass to Europe”, in Duncan R. Hook and David R.M. Gaimster (eds), Trade and Discovery: The Scientific Study of Artefacts from Post-Medieval Europe and Beyond, London, British Museum Press, 1995, p. 259-282.

25. Ibid., p. 259.

26. J. MeI, "The history, metallurgy and spread of paktong," op. cit., p. 33-55.

27. Ibid., p. 49-50. 
Society in Birmingham. ${ }^{28}$ The discovery of these archives confirmed the presumption in Bonnin's treatise why there were few commercial records of the trade of paktong. Among the archival papers, there is a record of a discussion between one of Boulton's retailers and two ship captains from the Honourable East India Company about creating a business opportunity involving taking orders for paktong from the East Indies. This presented historical evidence for Bonnin's "private commodity" assumption. ${ }^{29}$ More importantly, Pinn contributed more than one hundred items of paktong and German-silver from his family collection for experimental analysis, so the chemical results of items from his collection were used to distinguish paktong and German-silver. Regarding distinguishing between the chemical components paktong and German-silver, respectively, Pinn offers the following essential guidelines - that paktong's composition is concentrated within the range of $40-50 \%$ copper, $35-45 \%$ zinc and $5-15 \%$ nickel, while German-silver is within the range of 55-65\% copper, 20-25\% zinc and $15-20 \%$ nickel. The iron content of paktong is $1 \%-2.5 \%$, but Germansilver contains no more than $0.5 \% .{ }^{30}$ These parameters represent a significant contribution to our current understanding of these two alloys and especially significant for identifying original $18^{\text {th }}$-century paktong pieces.

The review of previous scholarship shows that the investigations examined the history of paktong in various fields, among which, the most long-lasting discussion is with the introduction of this metal to Britain. The famous British industrial revolutionaries Matthew Boulton and James Watt were both involved in the case of paktong in $18^{\text {th }}$ century Birmingham. Therefore, the following sections will reveal and focus on the unique significance of the metallurgical knowledge transfer to Sweden and Austria. In Chinese or English treatises on paktong research, these two European countries were seldom mentioned and discussed, but their participation of acquiring the manufacturing knowledge of Chinese paktong was of great importance. The merchants and scientists of both countries had associations with making the transmission efficiency as practitioners

28. Robert Schofield, The Lunar Society of Birmingham: A Social History of Provincial Science and Industry in Eighteenth-Century England, Oxford, Clarendon Press, 1963, p. 98.

29. A. Bonnin, Tutenag \& Paktong, op. cit., p. 32.

30. Keith Pinn, Paktong: The Chinese Alloy in Europe, 1680-1820, Antique Collectors Club Ltd, 1999, p. 62. 
and technicians respectively, or both, in bringing about the transfer of metallurgical knowledge inspired and influenced by China.

\section{Swedish and Austrian contributions and the innovation of paktong}

The Journal of Chemical Education in 1943 outlined the mysterious history of paktong transmitting from the East to the West:

Three hundred years have passed since that day when a great, storm-beaten East Indiaman swung slowly around in the Thames River and headed her bow towards the wharf. Home again! A year ago she had sailed away from London bound for the Orient. Now she was back with a cargo of tea and silk and spices and something new-exquisite metal articles such as no man in Europe had ever seen. They were made of a metal that shone with the soft luster of sterling silver. Yet they were certainly not silver, for this was a strong, hard metal. "Paktong" the Chinese called it, and they jealously guarded the secret of how it was made. As reports of the strange metal spread, European metal workers tried for generation after generation to produce an imitation paktong. They never knew why each different mixture produced only another failure until the middle of the eighteenth century when a new metal was identified by one Swedish scientist and recognized by another as the mysterious alloying metal that made paktong. ${ }^{31}$

As the story tells, a new metal was identified by a Swedish scientist, and it was undoubtedly nickel. The contribution was as a result of the analytical experiment of Axel Fredrik Cronstedt, who was a well-known Swedish mineralogist. Cronstedt's discovery of nickel was not concerned with Chinese paktong, but the proof of the existence of such element led to a better understanding of the metallic nature of the alloy. Later, one of his apprentices, Gustavus von Engeström, was regarded as the first scientist to obtain and examine the rough metal of Chinese paktong, and the metal sample came from Peter Johan Bladh, a Swedish East India Company supercargo in Canton.

31. International Nickel Company, "The Mystery of Paktong”, Journal of Chemical Educatio, $20, \mathrm{n}^{\circ} 4,1943$, p. 188. 
Engeström gave an account of his research and understanding of Chinese paktong in 1776. In his article, he originally and wrongly spelt paktong as "Packfong" which was a scribal error that endured for a long time in European countries. ${ }^{32}$ He mentioned Bladh had visited several times the East Indies and brought paktong with him from China. Engeström not only obtained wrought and mixed metal (copper-nickel-zinc alloy), but also acquired rough and unmixed one (smelted copper-nickel alloys). The rough metal came from the mines of Yunnan in China ${ }^{33}$, coming down to Canton by the river in the form of triangular rings, with an exterior diameter of 8 or 9 inches, and with a thickness of about 1.5 inches. ${ }^{34}$ Consequently, he pointed out that the metal must have been smelted from copper ore containing nickel. As one of the first Swedish merchants to bring paktong back to Stockholm, Bladh then joined the most famous scientists of the time in Sweden and focused on the analytical research of paktong - Engeström was among them. The experiments were made using a blow-pipe and only tried a little of paktong on coal, but it was enough to show that it contained nickel; a fact that later was confirmed by Engeström's experiments. Finally, the experimental results from Engeström showed that the proportions of nickel and copper were about 5 or 6 to 13 or 14 , and the nature of this metallic mixture was red rather than white. However, in Canton another metal was added, which made it silvery white; this proved to be zinc, also containing trace cobalt. After the preliminary examination carried out on paktong, Engeström intended to make it using Swedish nickel, hoping that someone would be able to solve the problem of using local nickel ores that contained a good deal of arsenic for smelting comparatively pure metal. ${ }^{35}$

Almost at the same time of Engeström's publication, in 1775, Torbern Bergman completed his research dissertation on nickel. He not only proved that Cronstedt's discovery was not pure nickel but also made significant efforts to refine considerably unblended nickel. However, the result was unsatisfactory for it always contained some iron as a result of the magnetic nature of both nickel and iron. In 1779, the young Johan Gadolin, who

32. A.Bonnin, Tutenag \& Paktong op. cit., p. 18.

33. Johan J. Gadolin, "Observationes de cupro albo Chinensium pe-tong vel pack-tong", Nova Acta Regia Societatis Scientiarum Upsaliensis, n 8, 1821, p. 137-157.

34. G. von Engeström, "Pak-Fong, En Chinesisk Huit Metall”, op. cit., p. 5-38.

35. Ibid. 
was a Swedish-Finnish citizen and a scientist famous for the discovery of the element called Yttria, had just moved to Uppsala University where Bergman taught him. At that time, Uppsala was the centre of chemistry in Sweden and Uppsala University was a pioneering research institute for chemical analysis. Gadolin submitted his doctoral dissertation in 1781 which he published and entitled De Analysi Ferri (On Analysis of Iron) under Bergman's instruction. During his stay in Sweden, Gadolin had the opportunity to contact and meet Bladh who gave him a sample of Chinese paktong for chemical analysis. The test results were published in his second dissertation De Cupro Albo Sinensi (On Chinese White Copper). ${ }^{36}$

In 1782, Sven Rinman, a Swedish chemist and mineralogist, continued to discuss the nature of iron and nickel in his treatise Försök till järnets historia (History of iron). ${ }^{37} \mathrm{He}$ also mentioned that he had experimented with testing a Chinese paktong plate, containing copper, nickel, zinc and iron. He then tried to make use of the local ores of arsenical nickel to imitate paktong, which resulted in a pale colour. When zinc was added into his metal, it became whiter; when the iron was added, the alloy became hard and durable. He finally established that Chinese paktong was no longer a mysterious metal. Rinman's paktong sample may also have been obtained from Bladh's collection from Canton. According to a list of Bladh's artefacts that were made after his death, there are some paktong utensils and the rough metal in it, which was well preserved in the Österbottens Historika Museum. $^{38}$

After the success of his dissertation on Chinese paktong, Gadolin also wrote an article on the same topic several years later. It not only contained his own previous and latest findings, but it also summarised the critical research from other scientists of his time. ${ }^{39}$ However, the most important discovery of his research in the early 1820s was his citation of an archival paper of Bladh which was recorded as having been written in Canton in

36. J.J. Gadolin, "Observationes de cupro albo Chinensium pe-tong vel pack-tong", op. cit. p. $145-151$.

37. Sven Rinman, Försök till Järnets Historia: Med Tillämpning För Slögder Och Handtwerk, Tryckt hos Petter Hesselberg, 1782.

38. Katri LaIne, "Benvikin Kartano Peter Johan Bladhin Kotina Ja Liikeyritysten Keskustana", Hist. Arkisto, no 45, 1939, p. 61-62.

39. J.J. Gadolin, "Observationes de cupro albo Chinensium pe-tong vel pack-tong," op. cit. p. 137-145. 
1781 and entitled Om Hvit Koppar (On White copper). It was a valuable report of an investigation conducted by Bladh himself when he was working at Canton. On the first page, he recorded how to alloy paktong with zinc or tutenag (viz spelter) in a precise percentage of each ingredient. Even though the Swedish scientists paid particular attention to understand the metallurgical constituents of paktong, it was still challenging for them to refine pure nickel from the local ores during the late $18^{\text {th }}$ century. As a result, the actual manufacturing imitating paktong in Sweden did not last a long time and was only on a small scale by Hans Peter Eggertz, Baron Johan Nordin, and J. G. Gahn. In 1816, they established a small plant at Falun for the manufacture of the alloy from nickeliferous ores of the Slaettberg and Kuso mines, but this plant was not in operation until 1821 when fire destroyed it.

In the early 1820s, a Chinese paktong tea-box was acquired by Johann Rudolf Ritter von Gersdorff, an Austrian mineralogist, mining expert and entrepreneur. He wanted to analyse it to have a clear understanding of this beautiful oriental object and its silvery metal surface decoration. He subsequently discovered that the metal on the box was made of nickel alloy. It is highly likely that this was the moment when he finally had the notion to reproduce and then manufacture his paktong. At the time Gersdorff discovered the metallic elements of Chinese paktong, he was a foreign honorary member of the Societät für die gesamte Mineralogie, a society of mineralogy in Germany whose President then was Johann Wolfgang von Goethe.

When Gersdorff was working in an Austrian mineral area, at an ore residue site, he had the opportunity to have access to experimental by-products of cobalt residues containing a high percentage of nickel with trace arsenic and cobalt from a smaltite factory at Gloggnitz, in the Neunkirchen district of Lower Austria. He took advantage of having access to these residues. As a result of experimentation, he produced relatively pure nickel with the intention of creating something similar to Chinese paktong. He subsequently invented a different manufacturing process for producing paktong using pure nickel obtained from the cobalt residues. When he succeeded in producing a similar alloy to paktong, he immediately registered a patent in Vienna ${ }^{40}$ and then produced his products, which he called Packfong ${ }^{41}$,

40. Johann R. Gersdorff, Darstellung des Nickelmetalles, Nr. 2425, Wien, issued 1824.

41. Johann R. Gersdorff, "Ueber Das Packfong”, Annalen Der Physik 84, 1826, p. 103-106. 
as previously mentioned, initially from Engeström's scribal error. He went on to create his industrial factory in Schladming Valley, Austria. ${ }^{42}$

One of his European competitors in the manufacture of nickel at that time was Ernst August Geitner in Germany. He also used by-products of cobalt from Saxony that might be residues from the extraction of blue cobalt pigments and piled there since the 16th century. These residues accumulated in the dye and pigment factories in the form of useless waste; the Saxony pigment works were almost exclusively in the area of Schneeberg. After repeated comparisons and experiments, Geitner evolved a process of extracting and purifying nickel from the residues. ${ }^{43}$ It was similar to the process in Gersdorff's patent of 1824.

According to the patent's description, Gersdorff explained his process of producing pure nickel, and he made use of the nickel to combine with brass, or copper and zinc to produce a form of nickel alloy, using varying quantities of brass, copper and zinc to control the color of the finished product. ${ }^{44}$ In his following publication in the Annalen der Physik (Annals of Physics), he gave a detailed and innovative account of making an alloy of copper, nickel and zinc, named Packfong. He was one of the first to publish information on the compositions of the metal suitable for particular uses. For example, for spoons, ladles and two-pronged forks, an alloy consisting of 25 parts nickel, 50 parts copper and 25 parts zinc was recommended; for knife and fork handles, candle snuffers and sugar tongs, an alloy of 22 parts nickel, 55 parts copper and 23 parts zinc was recommended; for plates and wash-basins the suggested an alloy was 20 parts nickel, 60 parts copper and 20 parts zinc. It also stated that with the addition of $3 \%$ of lead to alloys of the last-mentioned type, the material was produced that was suitable for casting items such as candlesticks, spurs, bells and horse harnesses. Crucially the addition of zinc while melting the alloy in a crucible, it was of great necessity and significance to recuperate

42. Alfred WeIss, Nickel Im 19. Jahrhundert: Das Wirken von RudolfRitter von Gersdorff Und Rudolf Flechner Im Schladminger Berg-Und Hüttenwesen, Stadtgemeinde Schladming, 2002.

43. Hans-Henning Walter, Ernst August Geitner, 1783-1852: Chemiker, Metallurge, Erfinder Und Unternehmer: Tagung Vom 12. Bis 14. Juni 2008 in Der Saigerhütte Olbernhau-Grünthal Bei Freiberg in Sachsen, Freiberg (Sachsen), Drei-Birken-Verlag, 2008.

44. J.R. Gersdorff, Darstellung des Nickelmetalles, op. cit. 
the loss and evaporation of zinc when alloying; every pound of Packfong would require an extra ounce of zinc in the melting process. ${ }^{45}$

Field research in Schladming Valley has been conducted in Austria to gather additional information about Gersdorff and his production of his alloy. It was found out that the Gersdorff family estate still exists and the local museum of Schladming owns a collection from the old house. Within the collection is a clock with the old Gersdorff name inscribed on the back, and it is said that parts of the clock were made of the nickel alloy.

A family book, written by a descendant of Gersdorff, was shared and shown by the local museum director; it relates a brief history of Gersdorff in Schladming Valley. Some of the places in the valley were said to be manufacturing sites for Packfong or nickel, where the Gersdorff's factories were located; a fact that was known by only a few up until now. Fortunately, it was informed that a site located near the recent Nickel Museum in the valley, which was built basing on an abandoned house once occupied by Gersdorff that has since been restored. At the site, there were still many remains, slags and ores, to be found on site, most of which were scattered on the nearby lawns and inside exhausted channels. Very a few local people knew the detailed background of the origins and history of the house. The recent exhibition in the museum is more of an introduction to a history of nickel rather than a memorial museum for Gersdorff and his works. Some local Austrian researchers have written the history of Gersdorff and Schladming nickel production, but nobody has carried out scientific research on this site to discover any more historical and technical information.

\section{Experiment and results}

To better understand the said site in Schladming Valley and its final production in the old days, some slag samples were collected in one of the abandoned channels on the spot. They were later subjected to scientific analysis in the laboratory using a scanning electronic microscope (SEM) equipped with an energy-dispersive spectrometer (EDS) to reveal their technological characteristics. All slag samples frequently contain some small metallic particles, which can be seen clearly under the SEM examination. The EDS

45. J.R. Gersdorff, “Ueber Das Packfong”, op. cit., p. 103-105. 
analysis of these metallic particles provides some information about smelting process as well as its processing or final products. Table 1 gives the preliminary analytical results of different inclusions and matrices of the compositions of the slag samples.

\section{Table 1. - Chemical compositions about the slag samples from a site in Schladming Valley}

\begin{tabular}{|c|c|c|c|c|c|c|c|c|c|c|c|c|c|c|}
\hline \multirow{2}{*}{$\begin{array}{l}\text { Lab. } \\
\text { Num. }\end{array}$} & \multirow{2}{*}{$\begin{array}{c}\text { Scanning } \\
\text { part }\end{array}$} & \multicolumn{12}{|c|}{ Chemical compositions (wt.\%) } & \multirow{2}{*}{$\begin{array}{c}\text { Materials } \\
\text { and } \\
\text { Figures }\end{array}$} \\
\hline & & $\mathrm{Cu}$ & $\mathrm{Ni}$ & $\mathrm{Fe}$ & As & $\mathrm{Si}$ & $S$ & $\mathrm{P}$ & K & $\mathrm{Ca}$ & $\mathrm{Mg}$ & $\mathrm{Al}$ & $\mathrm{Mn}$ & \\
\hline \multirow{5}{*}{ SS01 } & $\begin{array}{c}\text { Scanning } \\
\text { dark } \\
\text { phase }\end{array}$ & - & 1.1 & 6.0 & - & 50.6 & 1.1 & - & 1.2 & 29.1 & 7.6 & 3.0 & 0.9 & - \\
\hline & $\begin{array}{c}\text { Scanning } \\
\text { dark } \\
\text { phase }\end{array}$ & - & 32.4 & 15.7 & 30.2 & 0.2 & 20.3 & 0.1 & 0.2 & 0.7 & - & - & 0.3 & - \\
\hline & $\begin{array}{c}\text { Scanning } \\
\text { dark } \\
\text { phase }\end{array}$ & - & 11.7 & 25.6 & 1.1 & 19.6 & 28.6 & 0.1 & 0.3 & 8.9 & 2.2 & 1.6 & 0.3 & - \\
\hline & $\begin{array}{l}\text { Metallic } \\
\text { particle }\end{array}$ & - & 22.5 & 36.4 & - & - & 40.5 & - & - & 0.5 & - & - & 0.2 & $\begin{array}{c}\text { Matte(Fe, } \\
\text { Ni, S) } \\
\text { Fig. } 1\end{array}$ \\
\hline & $\begin{array}{c}\text { Scanning } \\
\text { bright } \\
\text { phase }\end{array}$ & - & 32.2 & 17.0 & 18.0 & - & 25.4 & - & 0.1 & 0.7 & - & - & - & Fig. 2 \\
\hline \multirow{3}{*}{ SS02 } & $\begin{array}{c}\text { Scanning } \\
\text { bright } \\
\text { phase }\end{array}$ & - & 0.6 & 59.3 & - & - & 36.6 & - & 0.2 & 0.3 & - & - & 1.2 & - \\
\hline & $\begin{array}{c}\text { Scanning } \\
\text { bright } \\
\text { phase }\end{array}$ & - & 3.3 & 53.3 & - & - & 36.8 & - & 0.1 & 0.6 & - & - & 1.1 & Fig. 3 \\
\hline & $\begin{array}{c}\text { Scanning } \\
\text { dark } \\
\text { phase }\end{array}$ & - & 1.4 & 8.4 & 1.5 & 30.8 & 0.7 & - & 1.7 & 37.1 & 10.7 & 6.9 & 1.6 & - \\
\hline
\end{tabular}




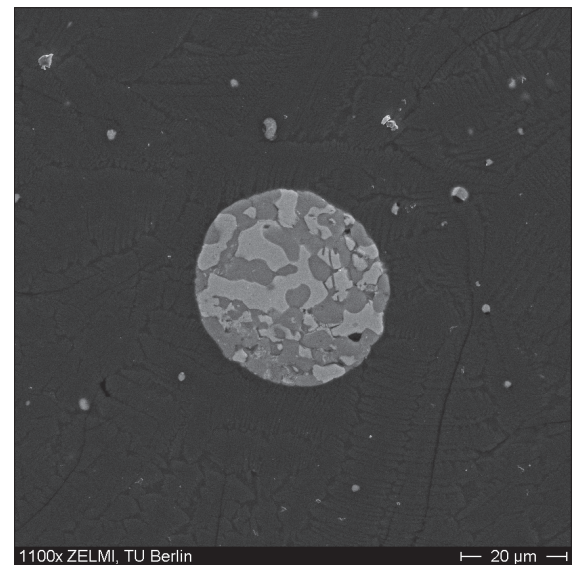

Fig. 1. - BSE image of metallic particle of slag (SS01)

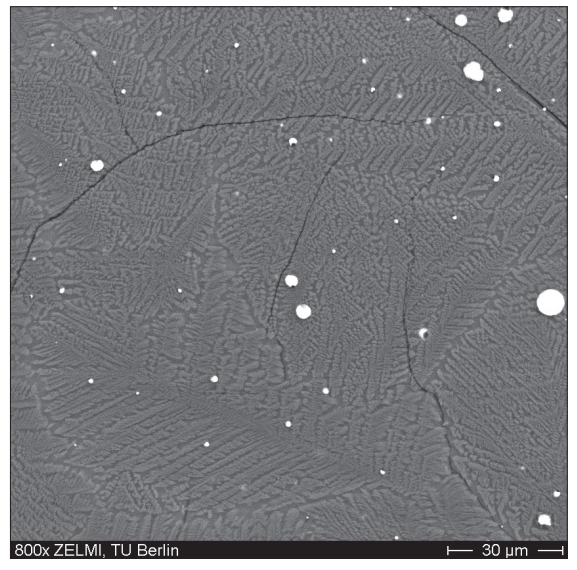

Fig. 2. - BSE image of slag matrix (SS01)

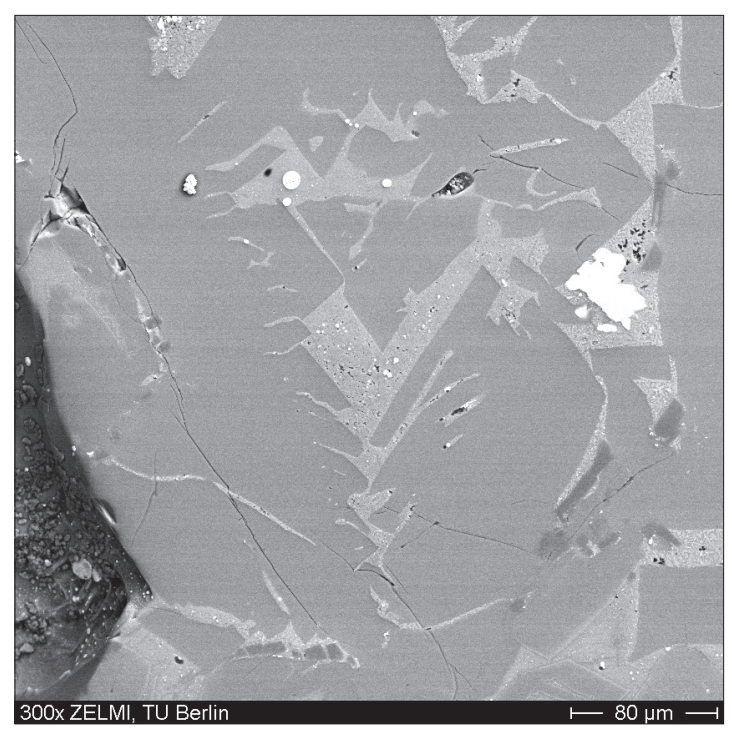

Fig. 3. - BSE image of slag matrix (SSO2)

The results from the scientific analysis show that Sample SS01 is the slag from the metallurgical process, probably, in purifying nickel in the site. The compositions for the glassy matrix and metallic particle from the slag indicate that it might be from the early procedure for roasting ores in the furnace, because of its high contents of nickel, arsenic and sulphur. This is likely to be relevant to the metallurgical treatment for niccolite. 
The metallic particle is a matte prill containing nickel, iron and sulphur of its averaged compositions. Then Sample SSO2 is a slag from the latter process for producing nickel, because of its low content of nickel in every partial analysis. The high iron content is typical in both samples, and it should be from the ores which contain not any nickel but ample iron. If the more iron content was not coming from niccolite, it is more possibility of mixing other ores with nickel ores as fluxing iron-rich quartz gangue, beneficially, for the metallurgical process. What kind of ores did the then smelter add into the furnace? Where were the ores mined from? It is hard to answer the questions right now, but further research and investigations on the nearby mountains must be conducted.

Not only were some slags taken from the site to analyse, but also two spoons stamped with an inscription "Packfong" on the back of their ladles were found among the local people's private collections. The optical micrograph of Sample TUB1403 shows that this Packfong item was wrought by hot-forging and cold-working techniques (Fig. III, colour plates illustrations). Sample TUB1454 contains trace lead, and the BSE image of Packfong spoon for sample TUB1403 shows some lead apparently inclusions on the surface. Fig. 4 shows that a particle of lead is nearly getting out from the surface under the SEM examination, because of the incomplete polishing work that the lead could be watched in that situation undoubtedly. The EDS results of both spoons provide that they should be made from an alloy of copper, nickel and zinc (Table 2) with very few lead. It is similar to the compositions of Chinese paktong, but showing not any difference in the percentage of each element according to the results of previous research, neither like Gersdorff's suggestions of making the alloy in the journal nor like the chemical elements from his patent. Could both spoons belong to the early artefacts of Packfong for resembling Chinese paktong, or they are just typical German-silver from a certain period? It needs more time and extant Packfong artefacts to examine and explain the characteristics of each chronology. The low content of nickel in the alloy is not a typical peculiarity of European items, according to former researches. However, it is the question whether the products of Packfong did exist or were used to make tableware for the market. Without any doubt, Gersdorff's scientific examination and publication of Packfong led to the existence of the two spoons that were found in the hands of the local people. 


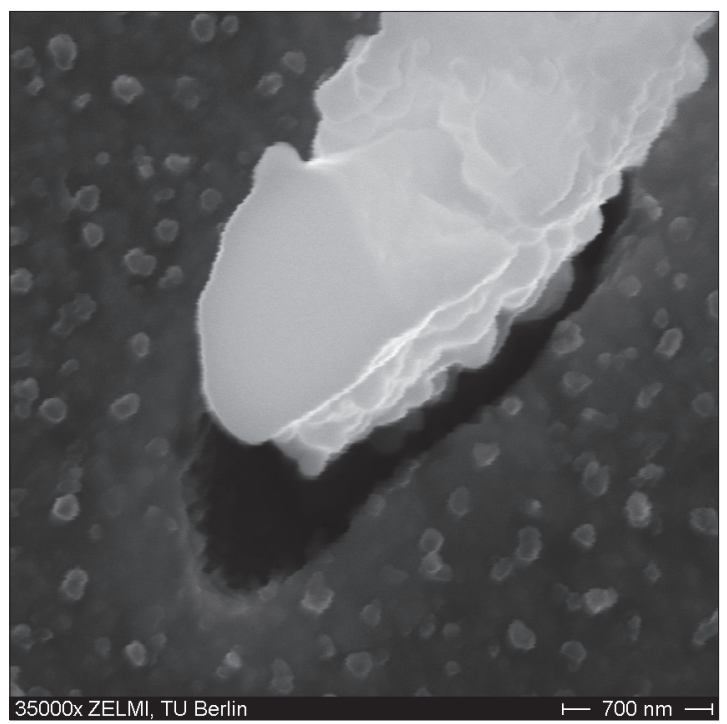

Fig. 4. - BSE image of a lead particle of Packfong spoon (TUB1403)

Table 2. - Chemical analytical results of two Packfong spoons

\begin{tabular}{|c|c|c|c|c|c|}
\hline \multirow{2}{*}{$\begin{array}{l}\text { Lab. } \\
\text { Num. }\end{array}$} & \multicolumn{4}{|c|}{ Chemical compositions (wt.\%) } & \multirow[t]{2}{*}{ Materials } \\
\hline & $\mathrm{Cu}$ & $\mathrm{Ni}$ & $\mathrm{Zn}$ & $\mathrm{Fe}$ & \\
\hline TUB1403 & 63.9 & 8.2 & 27.7 & 0.2 & Cu-Ni-Zn \\
\hline TUB1454 & 65.1 & 5.7 & 28.2 & 0.2 & Cu-Ni-Zn \\
\hline
\end{tabular}

\section{Epilogue}

As previously presented, the metallurgical knowledge of paktong was introduced into Sweden through both artefacts and textual investigative records. Peter Johan Bladh was a very important person, specifically in the introduction and examination of this Chinese alloy to Europe. $\mathrm{He}$ brought back early samples to scientists in Sweden at that time to understand this extraordinary Chinese metalwork, using the artefacts to do just this. Famous scientists at that time such as Gustavus von Engeström, Johan Gadolin and, likely, Sven Rinman helped Bladh to understand the nature of paktong through chemical analysis better. Bladh's invaluable report of alloying paktong at Canton was the earliest and most detailed textual records to mention metallurgical knowledge from the perspective 
of China. Despite the fact that Bladh and the Swedish scientists had a relatively early understanding of Chinese paktong, yet the reproduction of the alloy in Sweden was short-lived. The Swedes could not produce pure nickel or use similar methods of the complicated Chinese process to manufacture paktong.

The opportunity of making German-silver or European paktong fell to Johann Rudolf Ritter von Gersdorff in Austria, because he had a clear understanding of the metallurgical knowledge of paktong. He also made efforts to purify nickel from cobalt residues and used nickel to make his alloy for the family business. When the material mystery was solved, knowledge of it passed and understood from the East to the West. In this instance to Sweden and Austria, it inspired European scientists to create a similar outcome as in China but in the wave of the industrial revolution - in doing so it mirrors Chinese paktong, which was obtained, examined and emulated for industrial production. Comparison of the process of manufacturing the copper-nickel-zinc alloy in both China and Europe shows that there was a bit difference, but the people involved in Europe and China were able to make their technology appropriate for their usages and benefits. Therefore, the metallurgical knowledge of making the similar blended alloy with entirely different metallurgical thoughts, methods and raw materials was employed, probably also relying on the nickel mineral, environmental situation, practical tradition, technical experience or metallurgical cognition.

\section{Author}

Dr. Chao Huang is a postdoctoral researcher at the Department of History, Sun Yatsen University, Guangzhou, People's Republic of China. His main fields of interest are world history, history of technology, history of metallurgy and archaeometallurgy. Recent publication: The Research on Chinese Paktong and Its Transmission to Europe during the 18th and 19th Centuries, Aachen, Shaker Verlag, 2016. 